\title{
カチオン界面活性剂型モノマー存在下における水系でのスチレン のラジカル重合によるシリカゲル粒子のポリマーカプセル化*
}

\author{
長井勝利*1・片岡 浩明*1 ・倉本 憲幸*1
}

（受付 1992 年 10 月 30 日・審査終了 1993 年 2 月 11 日）

\begin{abstract}
要 旨 ジメチルアミノエチルメタクレートの長鎖アルキル四級塩タイプのカチオン界面活性剂型モノマー $\left(\mathrm{C}_{n} \mathrm{Br}\right.$ : 炭菜数 $n$ が 8,12,16 のアルキルプロマイド塩,ここでは主に $\mathrm{C}_{12} \mathrm{Br}$ を用いた)，スチレン(ST) および過硫 酸カリゥム (KPS) からなる水系での重合によるシリカゲル粒子のポリマーカプセル化について検討した． $\mathrm{C}_{n} \mathrm{Br}$ シリカゲル粒子に吸着するとともに, KPS と油溶性の塩を形成し， $\mathrm{C}_{n} \mathrm{Br}$ の吸着層に沈着した．この吸着層に ST 可溶化させて重合を行うと, ラテックスの生成をほとんど伴うことなく、シリカゲル粒子をポリマーカプセル化で きることを見いだした. 生成カプセル化粒子はポリマー含有量の増大に伴って表面被復率が大きくなり，ほぼ完全 に被復された複合粒子の合成も可能であることがわかった。
\end{abstract}

\section{1 緒言}

無機微粒子のポリマーカプセル化は主に無機微粒子の 表面処理法の一つとして, 粒子の液媒体あるいはポリ マーマトリックス中への分散性の向上を目的として検討 されてきだ), 2). また, ポリマーカプセル化複合粒子のポ リマー層を化学修飾することによって，機能性の複合粒 子として応用する展開も進められている3) .

無機微粒子をポリマーカプセル化する方法には，大別 して予め調製したポリマーあるいはポリマーラテックス を用いる方法と，無機微粒子存在下での重合による方法 がある. 後者の方法はポリマーの調製とカプセル化を一 段階で行うことができる点に利点がある．重合法による ポリマーカプセル化にもまた種々の方法が検討されてき ているがフ，微粒子表面で重合を選択的に進行させ，力 プセル化を効率よく行わせる有効な方法はまだ開発され てきていない.

我々は先にシリカゲル粒子存在下で, カチオン界面活 性剂型モノマーの一つである $\mathrm{C}_{12} \mathrm{Br}$ の水系でのラジカル 重合について検討し，シリカ粒子に吸着したモノマーの 優先的な重合によって, 均一にポリマーカプセル化され た複合粒子が得られることを報告した 始剂としてはカチオン性のアゾビスイソブチルアミジン 塩酸塩が高いカプセル化率を与え, KPS では重合は起こ らなかった．この界面活性剂の吸着層には, ミセル系と 同様に疎水性の化合物が可溶化する9). したがって，界 面活性剂型モノマーの吸着層に種々のビニルモノマーを

* 本報を「界面活性剂型モ/マーの重合に関する研究 第 6 報」とする.

*1 山形大学工学部物質工学科（\$992 米沢市城南 4-3-16）
可溶化させる方法を用いることによって, 重合後のカプ セル化ポリマー層の特性を変化させることができる.

このような無機粒子表面での界面活性阂の吸着層への ビニルモノマーの可溶化法を用いたポリマーカプセル化 についてはアニオン性の界面活性剤を用いた方法がすで に検討されているが(0), 11)，カプセル化状態やラテックス の副生の有無などについては詳しく報告されていない.

本研究では粒子表面で選択的に重合を進行させ，カプ セル化の効率を向上させる目的で, シリカ粒子表面にお けるカチオン界面活性剤型モノマーの吸着層にビニルモ ノマーを可溶化させ,さらにカチオン界面活性剂と KPS 間での油溶性の複塩の形成を利用して開始剂を粒子表面 の吸着層に沈着させる方法に基づいた水系での重合法に よるポリマーカプセル化について検討した，カチオン界 面活性剂型モノマーとしては $\mathrm{C}_{n} \mathrm{Br}$ （主に $n$ が 12 のラウ リル塩を用いた)，ビニルモノマーとしてはST, 開始郕 としてはKPSを用い, 生成したカプセル化粒子のカプ セル化部位について考察した。

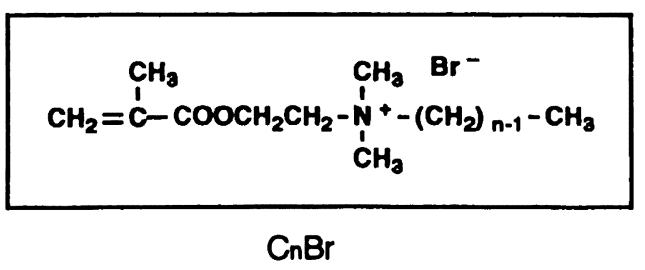

2 実験

\section{1 試薬}

カチオン界面活性斉型モノマーの $\mathrm{C}_{n} \mathrm{Br}$ ( (既報 ${ }^{12) .}{ }^{13)}$ の 方法に従って, ジメチルアミノエチルメタクレートとア 
ルキルブロマイド（nはアルキル鎖長を示す）との反応 によって合成し，酢酸エチルより再結晶によって精製し て用いた. ST (和光純薬工業(株)製) は $\mathrm{NaOH}$ 水溶液で 禁止剤を除去した後, 洗浄, 乾燥し, 減圧蒸留して精製 した. KPS は和光純薬工業(株)製のものをそのまま用い た. メチレンブルー (MB) は東京化成工業(株)製の分析 試薬用のものをそのまま用いた.

シリカゲル粒子は和光純薬工業(株)製のカラムクロマ トグラフィー用ワコーゲル（破砕状粒子）を篩分けし, 150〜200メッシュの区分のものを希塩酸および水で繰 り返し洗浄した後, $100^{\circ} \mathrm{C}$ で真空乾燥して用いた. BET 法により決定した比表面積は $375 \mathrm{~m}^{2} / \mathrm{g}$ であった。 細孔 径およびその分布についてはここでは特定しなかった。

水は比抵抗が $5 \times 10^{6} \Omega \mathrm{cm}$ 以上のイオン交換水をさら に蒸留して用いた。

\section{$2.2 \mathrm{C}_{n} \mathrm{Br}$ と KPS との反応}

シリカゲル存在下または不在下で, 所定濃度の $\mathrm{C}_{n} \mathrm{Br}$ と KPS の水溶液を混合し, $25^{\circ} \mathrm{C} て ゙ 1$ 時間振とうした後, 沈殿物をろ別乾燥し, 秤量した。一方, 滤液中の KPS は ヨウ素滴定法により定量した。

\section{3 シリカゲル粒子存在下での $\mathrm{C}_{12} \mathrm{Br}$ の定量}

所定濃度の $\mathrm{C}_{12} \mathrm{Br}$ 水溶液にシリカゲルを加え, KPS 存 在下の場合には KPS 水溶液を添加した後, $30^{\circ} \mathrm{C}$ で 1 時 間かき混せ，遠心分離した。その上澄液中の $\mathrm{C}_{12} \mathrm{Br}$ を指 示薬としてフロムフェノールブルーを, 滴定液としてテ トラフェニルホウ酸ナトリウム標準水溶液を用いる呈色 錯体法 ${ }^{14}$ により定量し, 水溶液中の $\mathrm{C}_{12} \mathrm{Br}$ 量を算出した. また, この値と初期溶液中の $\mathrm{C}_{12} \mathrm{Br}$ 量との差から吸着量 を計算した。

\section{4 シリカゲル粒子存在下での重合}

フラスコに $\mathrm{C}_{n} \mathrm{Br} € / マ ー の$ 水溶液とシリカゲル粒子 を入れ、これに KPS 水溶液を加え，ついで ST を添加し た。これらのそれぞれの段階では十分に混合した後に添
加を行った，反応系を窒素置換した後，かき混ぜながら $50^{\circ} \mathrm{C}$ で重合を行った。所定時間後，Fig. 1 に示した操作 法に従って, 沈殿物（カプセル化物）とラテックスポリ マーを分離した。 カプセル化ポリマーの生成量は真空乾 燥後の沈殿物の重量からシリカゲルの重量を差し引いて 算出した。 また, ラテックスポリマーは乾燥後, その重 量から収率を計算した。

\section{5 カプセル化シリカゲル粒子への MB の吸着}

シリカゲルの重量が $0.10 \mathrm{~g}$ になるようにカプセル化 シリカをとり，これに未処理のシリカゲル粒子を用いて 求めた飽和吸着量を参考にして, 過剩の $\mathrm{MB}$ をその水溶 液 $(0.25 \mathrm{mmol} / \mathrm{l})$ として加え, $30^{\circ} \mathrm{C}$ で 48 時間振とうし た後，上澄液の MB 浱度を紫外可視分光光度計 ((株)島 津製作所製 UV-180 型）を用いて定量し，初期溶液の濃 度の差から吸着量を算出した。

\section{6 粒子充媜フィルムの引張特性}

粉体を含むPST のジクロロメタン溶液からキャスト

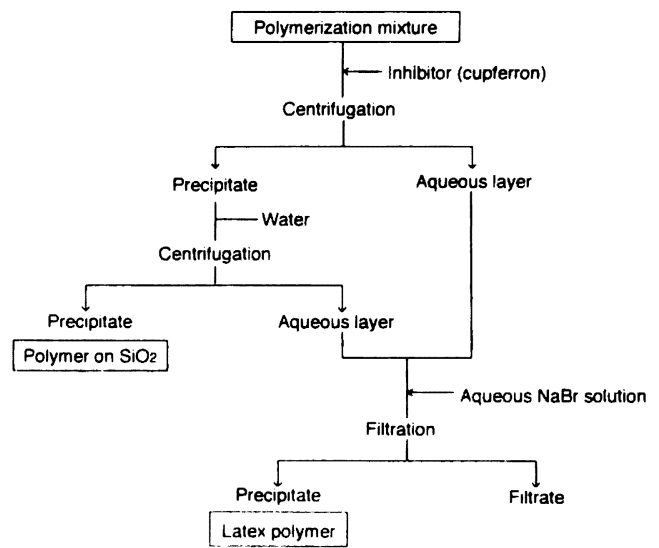

Fig. 1. Procedure for treatment of polymerization mixtures.

Table 1. Reaction of $\mathrm{C}_{12} \mathrm{Br}$ with KPS)

\begin{tabular}{clccc}
\hline Run No. & \multicolumn{1}{c}{$\mathrm{SiO}_{2}$} & $\begin{array}{c}\text { Moar ratio } \\
\mathrm{C}_{12} \mathrm{Br}: \mathrm{KPS}\end{array}$ & $\begin{array}{c}\text { Precipitate } \\
(\mathrm{mg})\end{array}$ & $\begin{array}{c}\text { KPS in aq. phase } \\
(\%)^{\mathrm{c})}\end{array}$ \\
\hline S-1 & Presence & $1: 2$ & 164 & 73 \\
S-2 & Absence & 11 & 162 & 71 \\
S-3 & Presence) & $1: 1$ & 162 & 48 \\
S-4 & Absence & $1 \prime$ & 161 & 46 \\
S-5 & Presence & $2: 1$ & 163 & 0 \\
S-6 & Absence & $\prime \prime$ & 165 & 0 \\
\hline
\end{tabular}

a) $\mathrm{C}_{12} \mathrm{Br}, 0.40 \mathrm{mmol}$; water, $20 \mathrm{ml}$; temp., $25^{\circ} \mathrm{C}$.

b) Theoretical yield of persulfate salt $\left[\left(\mathrm{C}_{12}\right)_{2} \mathrm{~S}_{2} \mathrm{O}_{8}\right], 169 \mathrm{mg}$.

c) Percentage to initial amount, determined by iodometric titration.

d) $\mathrm{SiO}_{2}, 0.50 \mathrm{~g}$. 
カチオン界面活性剤型モノマー存在下における水系でのシリカゲル粒子のポリマーカプセル化

Table 2. Elemental analysis of persulfate salts ${ }^{\text {a) }}$

\begin{tabular}{clccc}
\hline \hline Salt & & $\mathrm{C}(\%)$ & $\mathrm{H}(\%)$ & $\mathrm{N}(\%)$ \\
\hline$\left(\mathrm{C}_{8}\right)_{2} \mathrm{~S}_{2} \mathrm{O}_{8}$ & Calcd. & 52.4 & 8.80 & 3.82 \\
& Found & 52.1 & 8.76 & 3.63 \\
$\left(\mathrm{C}_{12}\right)_{2} \mathrm{~S}_{2} \mathrm{O}_{8}$ & Calcd. & 56.8 & 9.57 & 3.31 \\
& Found & 56.9 & 9.97 & 3.21 \\
$\left(\mathrm{C}_{16}\right)_{2} \mathrm{~S}_{2} \mathrm{O}_{8}$ & Calcd. & 60.2 & 10.1 & 2.92 \\
& Found & 60.1 & 10.0 & 2.78 \\
\hline
\end{tabular}

2) Salts were obtained at a molar ratio of $\mathrm{C}_{n} \mathrm{Br}$ to KPS of 3 in aqueous solution at room temperature.

b) Calcd. for $\left[\mathrm{C}_{n+8} \mathrm{H}_{2(n+8)} \mathrm{NO}_{22}\right]_{2} \mathrm{~S}_{2} \mathrm{O}_{8}$.

Table 3. Solubilities of persulfate salts ${ }^{2}$

\begin{tabular}{lccc}
\hline \hline \multicolumn{1}{c}{ Solvent } & $\left(\mathrm{C}_{8}\right)_{2} \mathrm{~S}_{2} \mathrm{O}_{8}$ & $\left(\mathrm{C}_{12}\right)_{2} \mathrm{~S}_{2} \mathrm{O}_{8}$ & $\left(\mathrm{C}_{16}\right)_{2} \mathrm{~S}_{2} \mathrm{O}_{8}$ \\
\hline Diethyl ether & - & - & - \\
Ethyl acetate & \pm & \pm & \pm \\
Chloroform & + & + & + \\
Tetrahydrofuran & + & + & \pm \\
Acetone & + & + & \pm \\
Dimethylformamide & + & + & + \\
Methanol & + & + & + \\
Water & \pm & \pm & \pm \\
Methyl methacrylate & \pm & \pm & \pm \\
Styrene & \pm & \pm & \pm \\
Acrylonitrile & + & + & + \\
\hline
\end{tabular}

a) + , soluble; \pm , soluble on heating; - , insoluble.

Preparation of salts: see Table 2.

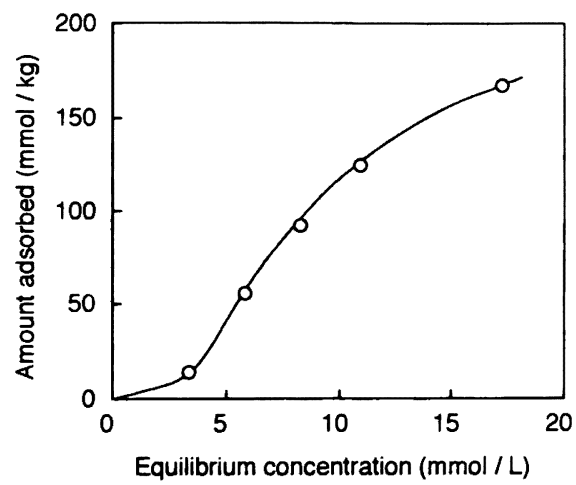

Fig. 2. Adsorption isotherm of $\mathrm{C}_{12} \mathrm{Br}$ onto $\mathrm{SiO}_{2}$ particles in aqueous solution at $30^{\circ} \mathrm{C}$. $\mathrm{SiO}_{2}, 1.0 \mathrm{~g} ; \mathrm{C}_{12} \mathrm{Br}$ solution, $25 \mathrm{ml}$.

したPST フィルムを $30^{\circ} \mathrm{C}$ で一尽夜真空乾燥した後, 試 呀片を作製した。テンシロン（東洋ボールドウイン(株) 製 UTM-III-500 型) を用いて, 室温で, 伸張速度 $5 \mathrm{~mm} /$ minで, 引張特性を評価した.

\section{3 結果と考察}

\section{$3.1 \mathrm{C}_{n} \mathrm{Br}$ と KPS 間での複塩の形成}

Table 1 に水溶液中での $\mathrm{C}_{12} \mathrm{Br}$ と KPS 間での塩の形成 について検討した結果を示した，両者の水溶液を混合す ると白濁し，しだいに沈殿物として沈降する. Table 1 に 見られるように，沈殿物の収量は両者の間で $2: 1$ の組 成の複塩が生成した時の理論値に近い値となっており, ほぼ定量的に塩が生成する。この沈殿物の生成量はシリ カゲル粒子の有無にはほとんど影響されないが，シリカ ゲル存在下では沈殿物の沈降が非常に速くなることが観 測された。一方，過剩の KPS は水溶液中に溶存してお り，表に示した水相での KPS の量は 2:1 の複塩が生成 した場合に計算される値とほぼ一致している。これらの 結果は混合組成およびシリカゲル粒子の有無に関係な く, 両者の間で $2: 1$ の塩が形成し，KPSに対して $\mathrm{C}_{12} \mathrm{Br}$ のモル比が 2 以上の条件では KPS は液相には存在しな くなることを示している.

Table 2 は $\mathrm{C}_{8} \mathrm{Br}, \mathrm{C}_{12} \mathrm{Br}, \mathrm{C}_{16} \mathrm{Br}$ と KPS との塩の元素分 析值を示した. いずれの塩も $2: 1$ の組成の計算値と良 く一致している.これらの塩の種々の溶媒およびビニル モノマーへの溶解性を Table 3 に示した. 塩は表に示し た溶媒ではジェチルエーテル以外の比較的広い範囲の有 機溶媒に室温あるいは加温して溶解した。加温時には塩 は水にも溶解するが，有機溶媒やモノマー類の場合の方 が溶解しやすい傾向が見られ, 複塩は全体的に油溶性の 特性を示すようになる.

\section{2 重合系での $\mathbf{C}_{12} \mathrm{Br}$ の溶存状態}

シリカ粒子は等電点 $(2.2)^{(3)}$ が低く，水中では負に帯 電しているため, カチオン界面活性剤を吸着する. Fig. 2 にここで用いたシリカゲル粒子への $\mathrm{C}_{12} \mathrm{Br}$ の水溶液中で の吸着等温線を示した，一般に，粒子の表面電荷と反対 の電荷を有する界面活性剂の吸着では，活性剂の平衡濃 度が臨界ミセル洤度 $(\mathrm{cmc})$ 以上になると飽和するが'16), 本系では $\mathrm{cmc}\left(25^{\circ} \mathrm{C} \text { で } 6 \mathrm{mmol} / l\right)^{12)}$ 以上でも吸着量が増 大した。 この原因は現在のところ明らかではないが, 恐 らくシリカゲルの多孔性, 特にその細孔径に関係がある 
と思われる ${ }^{17)}$.

Fig. 3 はこの系 KPS を添加した時の溶液中のフリー の $\mathrm{C}_{12} \mathrm{Br}$ 量の変化を示したものである. KPS 量の増大と ともに, 溶液中のフリーの $\mathrm{C}_{12} \mathrm{Br}$ 濃度は低下している. この濃度の低下は破線で示した塩の形成による低下より も急激で, KPS の添加によって無添加の場合よりも吸着 量が増大している. これは吸着層における $\mathrm{C}_{12} \mathrm{Br}$ の電荷 が KPS との塩形成によって低下するため, 吸着量の増 大を引き起こしたものと思われる.このような吸着量の 増大は界面活性剤に対して反対の電荷を持つ多価イオン を添加した時に起こることが知られており ${ }^{16)}$, さらに 3.1 であ示したようにシリカゲル粒子存在下では生成し た塩の沈降が非常に速いことなどの結果から, 塩の形成 は主にシリカ粒子表面での $\mathrm{C}_{12} \mathrm{Br}$ の吸着層で起こってい ると考えられる.

Fig. 3 の条件では, KPS の添加量が $0.1 \mathrm{mmol}$ 以上の 領域では $\mathrm{C}_{12} \mathrm{Br}$ の濃度は cmc 以下となる.この系にスチ レンを可溶化するとフリーの $\mathrm{C}_{12} \mathrm{Br}$ 濃度は若干ではある がさらに低下した。

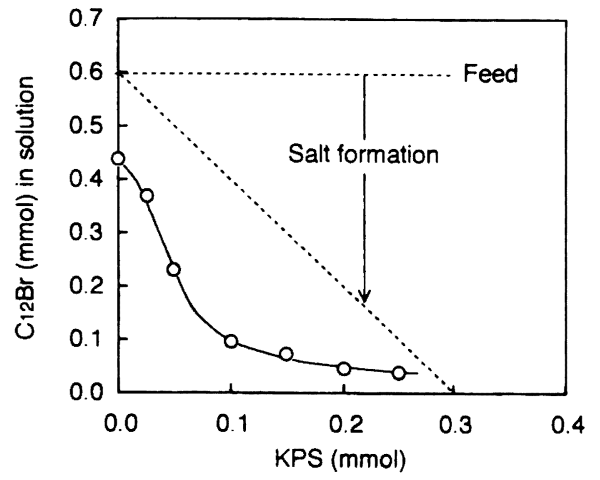

Fig. 3. Variation of amount of $\mathrm{C}_{12} \mathrm{Br}$ in aqueous phase with amount of KPS in the presence of $\mathrm{SiO}_{2}$ particles at $30^{\circ} \mathrm{C}$. $\mathrm{SiO}_{2}, 1.0 \mathrm{~g} ; \mathrm{C}_{12} \mathrm{Br}, 0.60 \mathrm{mmol}$; water, $25 \mathrm{ml}$.

\section{3 シリカゲル粒子存在下における $\mathrm{C}_{12} \mathrm{Br} / \mathrm{KPS}$ 系で の重合}

水系においてシリカゲルの存在下で $\mathrm{C}_{12} \mathrm{Br}$ の重合をア ゾビスイソブチルアミジン塩酸塩ヤアソビスイソブチロ ニトリルなどの開始剤を用いて行った場合，カプセル化 ポリマーとテックスポリマーが生成した. 一方, KPSを 開始剂とした場合には重合は全く起こらなかったが， シリカゲル不在下の場合には，ラテックスが高収率で生 成する (Fig. 4 での KPS 量が $0.05 \mathrm{mmol}$ の場合). そこ で, $\mathrm{C}_{12} \mathrm{Br} / \mathrm{ST} / \mathrm{KPS}$ 系でのカプセル化を検討する前に, $\mathrm{C}_{12} \mathrm{Br} / \mathrm{KPS}$ 系での重合における KPS 量の依存性につい て調べた. Fig. 4 に示したように, シリカゲル存在下で は KPSを $0.13 \mathrm{mmol}\left(\mathrm{C}_{12} \mathrm{Br}\right.$ に対して約 $\left.10 \mathrm{~mol} \%\right)$ 以上 添加しないと重合が起こらない，この系での生成ポリ マーはカプセル化ポリマーのみで，ラテックスの生成は ほとんど見られなかった。この結果はKPSを開始剤と して用いる場合には， $\mathrm{C}_{12} \mathrm{Br}$ に対して KPS の添加量を比 較的高くする必要があることを示している.

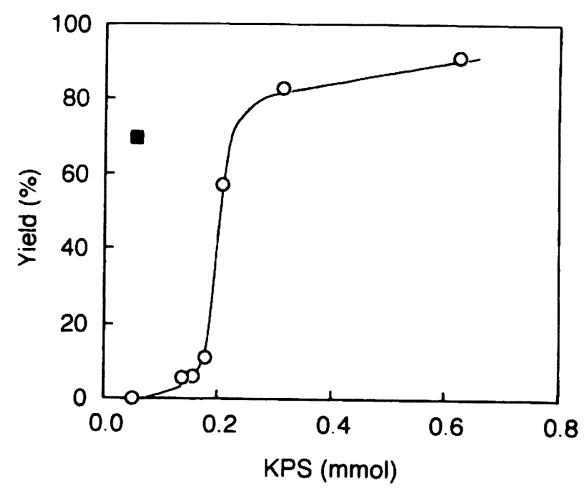

Fig. 4. Polymerization of $\mathrm{C}_{12} \mathrm{Br}$ in the presence and absence of $\mathrm{SiO}_{2}$ particles at $50^{\circ} \mathrm{C}$ for $24 \mathrm{~h}$. $\mathrm{SiO}_{2}, 1.0 \mathrm{~g}$; $\mathrm{C}_{12} \mathrm{Br}, 1.25 \mathrm{mmol}$; water, $25 \mathrm{ml}$. $\square$, Latex formed in the absence of $\mathrm{SiO}_{2} ; \mathrm{O}$, polymer formed in the presence of $\mathrm{SiO}_{2}$.

Table 4. Polymerization of ST in the presence of $\mathrm{C}_{12} \mathrm{Br}$ and $\mathrm{SiO}_{2}$ particles (1)

\begin{tabular}{|c|c|c|c|c|c|c|c|}
\hline \multirow{2}{*}{ Run No. } & \multirow{2}{*}{$\begin{array}{c}\mathrm{C}_{12} \mathrm{Br} \\
(\mathrm{mmol})\end{array}$} & \multirow{2}{*}{$\begin{array}{c}\mathrm{ST} \\
(\mathrm{mmol})\end{array}$} & \multirow{2}{*}{$\begin{array}{l}\text { Time } \\
\text { (h) }\end{array}$} & \multicolumn{2}{|c|}{ Polymer yield (\%) } & \multirow{2}{*}{$\begin{array}{c}\text { Polymer on } \mathrm{SiO}_{2} \\
\left(w t \% \text { to } \mathrm{SiO}_{2} \text { ) }\right.\end{array}$} & \multirow{2}{*}{$\begin{array}{c}\text { Color of } \\
\left.\text { dyed solid }^{b}\right)\end{array}$} \\
\hline & & & & On $\mathrm{SiO}_{2}$ & Latex & & \\
\hline 01 & 0 & 2.0 & 24 & 10.8 & 3.2 & 2 & Dark bule \\
\hline 02 & 0.60 & 3.0 & 0.5 & 31.8 & 0.5 & 18 & Blue \\
\hline 03 & $" \prime$ & $" \prime$ & 1 & 63.1 & 0.3 & 35 & "I \\
\hline 04 & $" \prime$ & $" \prime$ & 12 & 78.1 & 0.4 & 43 & Pale bule \\
\hline 05 & $\prime \prime$ & " & 24 & 87.9 & 0.5 & 49 & " \\
\hline
\end{tabular}

a) $\mathrm{SiO}_{2}, 1.0 \mathrm{~g}$; KPS, $0.20 \mathrm{mmol}$; water, $25 \mathrm{ml}$; temp., $50^{\circ} \mathrm{C}$.

b) Color of encapsulated $\mathrm{SiO}_{2}$ after dyeing with methylene blue in water. 
カチオン界面活性剤型モノマー存在下における水系でのシリカゲル粒子のポリマーカプセル化

Table 5. Polymerization of ST in the presence of $\mathrm{C}_{12} \mathrm{Br}$ and $\mathrm{SiO}_{2}$ particles (2)

\begin{tabular}{|c|c|c|c|c|c|c|c|}
\hline \multirow{2}{*}{ Run No. } & \multirow{2}{*}{$\begin{array}{c}\mathrm{C}_{12} \mathrm{Br} \\
(\mathrm{mmol})\end{array}$} & \multirow{2}{*}{$\begin{array}{c}\text { ST } \\
(\mathrm{mmol})\end{array}$} & \multirow{2}{*}{$\begin{array}{l}\text { Time } \\
\text { (h) }\end{array}$} & \multicolumn{2}{|c|}{ Polymer yield (\%) } & \multirow{2}{*}{$\begin{array}{l}\text { Polymer on } \mathrm{SiO}_{2} \\
\left(w t \% \text { to } \mathrm{SiO}_{2}\right)\end{array}$} & \multirow{2}{*}{$\begin{array}{c}\text { Color of } \\
\text { dyed solid }\end{array}$} \\
\hline & & & & On $\mathrm{SiO}_{2}$ & Latex & & \\
\hline 05 & 0.60 & 3.0 & 24 & 87.9 & 0.5 & 49 & Pale blue \\
\hline 06 & $"$ & 5.0 & $"$ & 95.2 & 0.1 & 73 & " \\
\hline 07 & $" \prime$ & 10.1 & " & $88.5^{c)}$ & 1.5 & 114 & White \\
\hline 08 & 1.00 & 3.1 & " & 94.2 & 1.0 & 68 & Pale blue \\
\hline 09 & $"$ & 5.4 & $"$ & 96.8 & 0.3 & 95 & White \\
\hline 10 & $" \prime$ & 10.0 & $" \prime$ & $97.5^{\mathrm{c})}$ & 1.4 & 142 & " \\
\hline 11 & 1.60 & 3.1 & " & 67.6 & 19.4 & 65 & Pale blue \\
\hline 12 & $"$ & 5.0 & $"$ & 65.1 & 33.6 & 76 & " \\
\hline 13 & $"$ & 10.0 & $" \prime$ & 38.4 & 57.1 & 65 & $"$ \\
\hline
\end{tabular}

a) $\mathrm{SiO}_{2} 1.0 \mathrm{~g}$; KPS, $0.20 \mathrm{mmol}$; water $25 \mathrm{ml}$; temp., $50^{\circ} \mathrm{C}$.

b) Color of encapsulated $\mathrm{SiO}_{2}$ after dyeing tith methylene blue in water.

c) Partially coagulated.

Table 6. Polymerization of $\mathrm{ST}$ in the presence of $\mathrm{C}_{n} \mathrm{Br}$ and $\mathrm{SiO}_{2}$ particles")

\begin{tabular}{|c|c|c|c|c|}
\hline \multirow{2}{*}{ Run No. } & \multirow{2}{*}{$\mathrm{C}_{n} \mathrm{Br}$} & \multicolumn{2}{|c|}{ Polymer yield (\%) } & \multirow{2}{*}{$\begin{array}{c}\text { Color of } \\
\text { dyed solid }\end{array}$} \\
\hline & & On $\mathrm{SiO}_{2}$ & Latex & \\
\hline 14 & $\mathrm{C}_{8} \mathrm{Br}$ & 66.8 & 0.3 & Blue \\
\hline 05 & $\mathrm{C}_{12} \mathrm{Br}$ & 87.9 & 0.5 & Pale blue \\
\hline 15 & $\mathrm{C}_{16} \mathrm{Br}$ & 88.5 & 0.8 & " \\
\hline
\end{tabular}

a) $\mathrm{SiO}_{2}, 1.0 \mathrm{~g}$; $\mathrm{C}_{n} \mathrm{Br}, 0.60 \mathrm{mmol}$; ST, $3.0 \mathrm{mmol}$; KPS, $0.20 \mathrm{mmol}$; water, $25 \mathrm{ml}$; temp., $50^{\circ} \mathrm{C}$; time, $24 \mathrm{~h}$.

b) Color of encapsulated solid after dyeing with methylene blue in water.

\section{4 シリカゲル粒子存在下における $\mathrm{C}_{n} \mathrm{Br} / \mathrm{ST} / \mathrm{KPS}$ 系での重合}

Table 4 にシリカゲル粒子表面の $\mathrm{C}_{12} \mathrm{Br}$ の吸着層にス チレンを可溶化させた系での重合結果を示した，表の右 端の欄には重合後得られたシリカゲル粒子をメチレンブ ルー水溶液で染色した時の色を定性的に示した。

$\mathrm{C}_{12} \mathrm{Br}$ 不在下でのスチレンの重合ではポリマーの収率 は低く, 少量のラテックスも副生するが, この系に $\mathrm{C}_{12} \mathrm{Br}$ を添加すると高収率でカプセル化ポリマーが生成 し，ラテックスの生成はほとんど起こらない。この時, 得られたシリカゲル粒子は $\mathrm{C}_{12} \mathrm{Br}$ 不在下では濃青色に着 色するか，存在下で得られたものでは淡青色となり、シ リカゲル粒子表面でのポリマーの生成によってシリカゲ ルの表面が減少していることを示している. また，先に 示したように本実験条件下では液相での $\mathrm{C}_{12} \mathrm{Br}$ の濃度が $\mathrm{cmc}$ 以下になっているためラテックスの生成が少ないも のと思われる。

重合時間依存性を見ると, カプセル化ポリマーの生成 量は重合時間の增大ととあに大きくなるが, ラテックス の生成量はほとんど変化しない，本実験の条件下では， $\mathrm{KPS}$ は液相にはなく，またスチレンが $\mathrm{C}_{12} \mathrm{Br}$ の吸着層に
殆ど可溶化されているために, カプセル化ポリマーの生 成がシリカゲル粒子表面で起こり，ラテックスの生成を 経て進行しているものではないと考えられる.

Table 5 に $\mathrm{C}_{12} \mathrm{Br}$ および ST の仕込み量を変化させた時 の結果を示した．表の条件において， $\mathrm{C}_{12} \mathrm{Br}$ 量を 0.6 $\mathrm{mmol}$ から $1.0 \mathrm{mmol}$ に增大すると, カプセル化ポリマー の収率が若干高くなる。，一方， $1.6 \mathrm{mmol}$ まで増大する と, ラテックスの収率が非常に大きくなり，カプセル化 ポリマーの収率が低下する。 これは液相での $\mathrm{C}_{12} \mathrm{Br}$ 濃度 が増大し、液相での乳化重合が起こったためと考えられ る. $\mathrm{C}_{12} \mathrm{Br}$ 量が $1.6 \mathrm{mmol}$ 以外の系では, ST の添加量を增 大しても高収率でカプセル化ポリマーが生成するが, ST の添加量を $10 \mathrm{mmol}$ に增大すると一部凝集したカプセ ル化粒子の生成が見られた。一方, $\mathrm{C}_{12} \mathrm{Br}$ が $1.6 \mathrm{mmol}$ の 系では STを $10 \mathrm{mmol}$ 添加した場合でも凝集物の生成は 見られなかった。この結果はシリカゲル表面の吸着層に 可溶化できる ST 量に限界があることを示しており，力 プセル化ポリマーの生成が可溶化部位で起こっているこ とを示唆している. また, 最大可溶化量以上のモノマー を添加した場合には, 液相での重合によって生成したポ リマーあるいはポリマー粒子が疑集の原因になっている 
長井・片岡・倉本

Table 7. Characteristics of $\mathrm{SiO}_{2}$ encapsulated with PST

\begin{tabular}{|c|c|c|c|c|}
\hline \multirow{2}{*}{$\begin{array}{l}\text { Polymer on } \mathrm{SiO}_{2} \\
\left(w t \% \text { to } \mathrm{SiO}_{2}\right)\end{array}$} & \multicolumn{2}{|c|}{ Specific surface area ${ }^{a}$} & \multicolumn{2}{|c|}{ MB Adsorption ${ }^{b}$} \\
\hline & $\begin{array}{c}\text { Surface area } \\
\left(\mathrm{m}^{2} / \mathrm{g}\right)\end{array}$ & $\begin{array}{c}\text { Coverage }^{c)} \\
(\%)\end{array}$ & $\begin{array}{l}\text { Adsorption } \\
(\mathrm{mmol} / \mathrm{kg})\end{array}$ & $\begin{array}{c}\text { Coverage }^{\mathrm{d})} \\
(\%)\end{array}$ \\
\hline 0 & 375 & 0 & 14.8 & 0 \\
\hline 18 & 257 & 19 & 10.8 & 14 \\
\hline 52 & 54 & 78 & 2.3 & 76 \\
\hline 95 & 11 & 94 & 0.49 & 94 \\
\hline
\end{tabular}

-) Determined by BET method.

b) Conditions as in Fig. 5 .

c) Surface coverage calculated on specific surface area per $1 \mathrm{~g}$ of $\mathrm{SiO}_{2}$.

d) Surface coverage calculated on amount of adsorption per $1 \mathrm{~g} \mathrm{of} \mathrm{SiO}_{2}$.

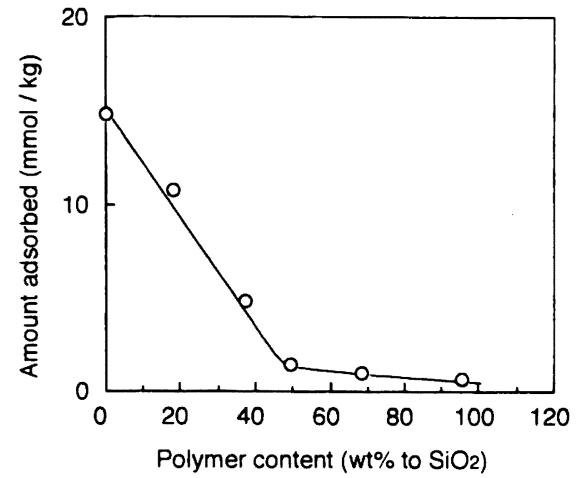

Fig. 5. Adsorption of $\mathrm{MB}$ onto $\mathrm{SiO}_{2}$ encapsulated with PST in water at $30^{\circ} \mathrm{C}$. Encapsulated $\mathrm{SiO}_{2}, 0.10 \mathrm{~g}$; MB solution $(0.25 \mathrm{mmol} / l), 20 \mathrm{ml}$.

あのと考えられる．このように，液相での界面活性剤濃 度を $\mathrm{cmc}$ 以下に抑え, さらに添加するモノマー量を吸着 層への最大可溶化量以下にすると，ラテックスの生成や 凝集をほとんど伴うことなく, 高収率でカプセル化ポリ マーを得ることができる，さらに，この系でのラテック スの生成が少ない原因は界面活性剤の吸着層での塩の形 成による開始剂の沈着にあ関係があると思われる.

生成したカプセル化粒子はポリマー含有量の増大と共 に定性的に色が薄くなり，MBによってほとんど着色さ れない複合粒子の調製も可能であった。

Table 6 には, アルキル鎖長の異なる 3 種の $\mathrm{C}_{\mathrm{n}} \mathrm{Br}$ を用 いた場合の結果を示した。これらのモ/マーはいずれも ミセル形成能を有しているが'12), 13)，より短鎖のオクチル 塩ではカプセル化ポリマーの収率が低くなっている。こ れは吸着層への ST の可溶化量が低下するためと思われ ろ.

\section{5 カプセル化シリカゲル粒子の特性}

Table 7 にポリマー含有量の異なるカプセル化粒子の

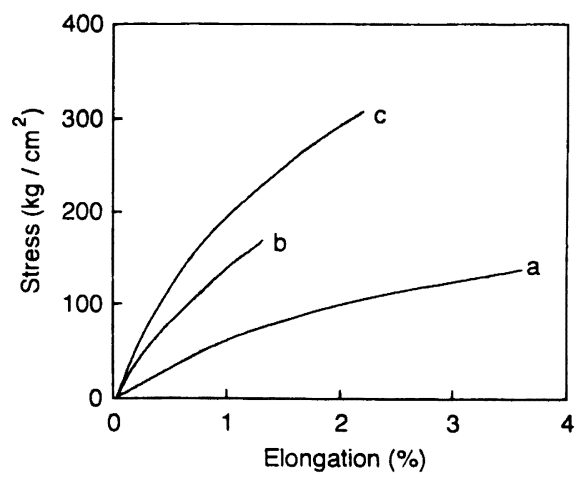

Fig. 6. Stress-strain curves for PST films. (a) PST film; (b) PST film impregnated with $\mathrm{SiO}_{2}$ particles; (c) PST film impregnated with PST-encapsulated $\mathrm{SiO}_{2}$ particles (polymer content, $65 \mathrm{wt} \%$ ).

BET 法によって決定した比表面積とMB の飽和吸着量 を示した，比表面積および吸着量ともポリマー含有量の 増大ととあに低下しており, シリカゲルの外表面および 細孔表面とあポリマーでカプセル化されていることを示 している. 表に示した比表面積および吸着量をシリカ 1 $\mathrm{g}$ 当たりに換算し，その值をもとに表面被覆率を算出し た. 両者の方法によって算出した被覆率は比較的良く一 致している.

カプセル化シリカゲル粒子への水溶液中での MB の 飽和吸着量とポリマー含有量との関係を Fig. 5 に示し た. 吸着量はカプセル化粒子のポリマー含有量の増大と ともに低下しており，この低下は単位重量当たりのシリ 力基準に換算した値をもとにした場合です同様な曲線と なった．カプセル化粒子がシリカ粒子とポリマー粒子の 単なる混合物の場合には, シリカ基準に換算した吸着量 はポリマー含有量にほとんど依存しない.したがって, 本重合法によって得られたカプセル化粒子はシリカゲル 粒子の表面（細孔内の表面も含む）をカプセルし，その 
表面被覆率の増大とともに吸着量が低下していることを 示している.

この場合，吸着量はポリマー含有量が約 $50 \mathrm{wt} \%$ にな るまでは, ポリマー含有量の增大とともに急激に低下し ており, 約 50 wt\% 以上ではその低下は緩やかとなって いる. この傾向はポリマー含有量が約 $50 \mathrm{wt} \%$ になる点 でカプセル化がほぼ完了し，この領域ではポリマーの生 成量が多くなるにつれて，カプセル化部位が増大するよ うにカプセル化が進行していることを示している。しか し、 $\mathrm{C}_{n} \mathrm{Br}$ の代わりにセチルトリメチルアンモニウムブ ロマイドを用いた同様な方法によるポリマーカプセル化 では, 用いるビニルモノマーによってカプセル化の進行 状態が異なるようである ${ }^{18}$.

\section{6 柆子充媜 PST フィルムの特性}

末処理およびカプセル化シリカゲル粒子を含む PST のジクロロメタン溶液からキャストしたフィルムは, 未 処理のシリカゲル粒子の場合には粒子が疑集して分散し たが, 一方 PST でカプセル化した粒子の場合には, 粒子 の分散性が向上し, 凝集はほとんど起こらなくなること が観測された。

Fig. 6 はPST, 未処理およびカプセル化シリカゲル粒 子を含む PST フィルムの引張特性を調べた結果を示し たものである. 未処理のシリカゲル粒子を充填したフィ ルムにおいても, 未充媜のフィルムに比べて, 破断强度 は若干大きくなるが, 破断伸度が低下する。，一方, PST カプセル化したシリカゲル粒子を充塤したフィルムで は、破断強度、破断伸度とも未処理の粒子を充填したも のに比べて向上している.

以上, 述べたように本重合法によるシリカゲル粒子の ポリマーカプセル化はラテックスの副生を伴うことな く, 効果的にカプセル化を行うことができる. さらに, この方法によるカプセル化法は重合性を持たないカチオ ン界面活性剤を用いても可能であるが(1), 重合性の界面
活性剂を用いる方法は共重合によって, 界面活性剂がポ リマー層に取り込まれるため, 重合後界面活性剤を除去 する必要がないと言う利点を有している.

\section{文献}

1) R. Kroker, M. Schneider, and K. Hamman, Progr. Org. Coatings, 1, 23 (1972).

2) 小野贲之, 山口 格, 高分子, 34, 90 (1985).

3) O. Itabashi and T. Goto, Chem. Ind. (London), 287 (1986).

4) T. M. Suzuki, O. Itabashi, T. Goto, T. Yokoyama, and T. Kimura, Anal. Sci., 2, 391 (1986).

5) T. M. Suzuki, O. Itabashi, and T. Goto, Bull. Chem. Soc. Jpn., 60, 2839 (1987).

6) 板橋 修，後藤富雄，森谷博繁，日本化学会誌， 1600 (1987).

7) 長井勝利, 高分子加工, 39, 537 (1990).

8) K. Nagai, Y. Ohishi, K. Ishiyama, and N. Kuramoto, J. Appl. Polym. Sci., 38, 2183 (1989).

9) J. Wu, J. H. Harwell, and E. A. O'Rear, Langmuir, 3, 531 (1987).

10) K. Meguro, T. Yabe, S. Ishioka, K. Kato, and K. Esumi, Bull. Chem. Soc. Jpn., 59, 3019 (1986).

11) K. Esumi, N. Watanabe, and Meguro, Langmuir, 7, 1775 (1991).

12) K. Nagai, Y. Ohishi, H. Inaba, and S. Kudo, J. Polym. Sci., Polym. Chem. Ed., 23, 1221 (1985).

13) K. Nagai and Y. Ohishi, J. Polym. Sci., Polym. Chem. Ed., 25, 1 (1987).

14) J. T. Cross, "Cationic Surfactants," E. Jungermann, Ed., Dekker, New York (1970), p. 419.

15) G. A. Parks, Chem. Rev., 65, 177 (1965).

16) M. J. Rosen, "Surfactants and Interfacial Phenomena," Wiley, New York (1987).

17) H. Zhi, M. Ji-Ming, and G. Ti-Ren, Acta Chimica Sinica (Engl. Ed.), 106 (1989).

18）長井勝利, 佐竹英哉, 西下 修, 松本陽美, 橋本寿雄, 城 戸淳二, 倉本憲幸、第 7 回高分子ミクロフェ了討論会講演 要旨集 (1992), p. 155.

Polymer Encapsulation of Silica Gel Particles by Radical Polymerization of Styrene in the Presence of Cationic Surface-Active Monomers in Aqueous System*

Katsutoshi NAGAI ${ }^{* 1}$, Hiroaki KATAOKA*1, and Noriyuki KURAMoto*1

*Studies on Polymerization of Surface-Active Monomers VI.

*1 Department of Materials Science and Engineering, Faculty of Engineering, Yamagata University (Jonan 4-3-16, Yonezawa, 992 Japan)

Polymer encapsulation of porous, silica gel particles by radical polymerization of styrene (ST) with potassium persulfate (KPS) in the presence of a cationic surface-active monomer in aqueous system was investigated. The surface-active monomers used here were quaternary salts $\left(\mathrm{C}_{8} \mathrm{Br}, \mathrm{C}_{12} \mathrm{Br}\right.$ and $\mathrm{C}_{16} \mathrm{Br}$, mainly $\left.\mathrm{C}_{12} \mathrm{Br}\right)$ of dimethylaminoethyl methacrylate with $n$-alkyl bromide having 8,12 , and 16 carbon atoms, respecitvely. The cationic monomer not only adsorbed onto silica gel particles but also formed an oil-soluble salt with KPS, which deposited onto adsorbed layers of the cationic monomer on the surface of the particles. The polymerization of ST solubilized into the adsorbed layers of cationic monomer was found to afford polymer-encapsulated particles with little formation of the latex polymer. The surface coverage of the resultiong particles increased with increase in the polymer content and nearly completely 
長井・片岡・倉本

encapsulated particles were also obtained by the present encapsulation method.

KEY WORDS Polymer Encapsulation / Silica Gel Particles / Radical Polymerization / Styrene / Cationic SurfaceActive Monomer / Potassium Persulfate / Aqueous System /

(Received October 30, 1992: Accepted February 11, 1993) [Kobunshi Ronbunshu, 50(4), 263-270 (1993)] 